\title{
Silage of Intercropping Corn, Palisade Grass, and Pigeon Pea Increases Protein Content and Reduces In Vitro Methane Production
}

\author{
Beatriz Ligoski ${ }^{1}$, Lucas Ferreira Gonçalves ${ }^{1}$, Flavio Lopes Claudio ${ }^{2}$, Estenio Moreira Alves ${ }^{2}$ (D), \\ Ana Maria Krüger ${ }^{3}$, Beatriz Elisa Bizzuti ${ }^{3}$, Paulo de Mello Tavares Lima ${ }^{3}$, Adibe Luiz Abdalla ${ }^{3}$ \\ and Tiago do Prado Paim ${ }^{2, * \mathbb{D}}$ \\ 1 Animal Sciences, Goiano Federal Institute of Education, Science and Technology Campus Rio Verde, \\ Rio Verde, GO 75909-120, Brazil; bia06_@hotmail.com (B.L.); ferreiralucas1205@gmail.com (L.F.G.) \\ 2 Animal Production Laboratory, Goiano Federal Institute of Education, Science and Technology Campus \\ Iporá, Iporá, GO 76200-000, Brazil; flavio.claudio@ifgoiano.edu.br (F.L.C.); \\ estenio.moreira@ifgoiano.edu.br (E.M.A.) \\ 3 Centro de Energia Nuclear na Agricultura-CENA, Universidade de São Paulo-USP, \\ Piracicaba, SP 134160-000, Brazil; anakruger@usp.br (A.M.K.); beatrizbizzutti@usp.br (B.E.B.); \\ pmtlima@cena.usp.br (P.d.M.T.L.); abdalla@cena.usp.br (A.L.A.) \\ * Correspondence: tiago.paim@ifgoiano.edu.br; Tel.:+55-64-3674-0467
}

Received: 11 October 2020; Accepted: 2 November 2020; Published: 13 November 2020

\begin{abstract}
Legume-grass intercropping systems are a sustainable option to improve nutritional quality of animal feed and decrease livestock greenhouse gas emissions. Thus, the present study evaluated yield, chemical composition and in vitro gas production of silages produced with intercropped palisade grass (Urochloa brizantha. (A.Rich.) R.D.Webster), pigeon pea (Cajanus cajan cv. Super N) and corn (Zea mays. L.). Forage was harvested and placed inside micro-silos, which were opened after 100 days and samples were collected for chemical composition and in vitro gas production analyses. Intercropped silage had higher crude protein, acid detergent fiber, and lignin content than corn silage. Moreover, intercropped silage decreased total gas and methane production. Therefore, intercropped silage showed potential to increase conserved feed nutritional quality and reduce methane emissions in livestock production systems.
\end{abstract}

Keywords: Cajanus cajan; $\mathrm{CH}_{4}$; legume; Urochloa brizantha

\section{Introduction}

Crop-livestock integrated systems (CLIS) involve the time-space planning of crops cultivation and livestock grazing at the same area [1,2]. These systems explore the synergism and emergent properties coming from the interplays between soil-plant-animal-atmosphere [3]. Well-managed integrated systems increase the organic matter content in soils with intensification of nutrient cycling, coupling carbon, nitrogen, and phosphorus cycles [4-6]. Therefore, CLIS are a sustainable option to produce legumes (peas and beans) and grains (corn, rice, sorghum, etc.) and animal products (meat, milk, and wool).

The intercropping of corn with tropical grasses, mainly Urochloa, is already widely used in commercial Brazilian mid-west farms, due to increased biomass covering the soil and also root biomass, which promotes soil fertility improvement in the long term [7,8] and soil carbon stock [9]. Therefore, many studies have been done with corn, sorghum, and millet intercropped with tropical forage grasses, aiming to grain production, silage and/or grazing forage during the dry season [10-15]. 
Recently, the introduction of legumes into these systems has been evaluated, mostly looking for higher biomass production and improvement of biological activity of the soil [16]. Moreover, the deep roots of some legumes can increase the nutrient cycling [17,18], improve the structure and permeability of the soil, enhancing water infiltration [19], and intensifying the biological activity, leading to organic matter increase $[20,21]$.

Pigeon pea (Cajanus cajan) is one of the main species able to increase the nutritional quality of forage and biological diversity in the production system [22,23]. Several studies highlight positive results to corn when intercropped with grass and legumes simultaneously [24-26]. Ferreira et al. [27], evaluating the intercropping of corn with palisade grass (Urochloa brizantha cv. BRS Paiaguás) and pigeon pea, demonstrated that the legume did not affect corn yield and increased crude protein of silage. In addition, Melesse et al. [28] reported C. cajan as a potential species in mitigating methane $\left(\mathrm{CH}_{4}\right)$ production.

Livestock production is pointed out as important contributing factor for climatic changes due methane emission from enteric fermentation. Improving animal performance in tropical countries is a key strategy to meet the demand for animal protein, while reducing greenhouse gas (GHG) emissions and improving resource use efficiency [9]. There are opportunities to improve and sustain animal performance through animal genetics, animal health, quantity, and quality of feed and animal nutrition [9]. Legumes and grasses intercropping systems stands out as one opportunity to reduce environmental impact of animal production, due reduction in ruminal methanogenesis and increased protein supply for the animals [28].

Based on the hypothesis that corn, palisade grass and pigeon pea intercropping can produce a high-quality silage with decreased enteric $\mathrm{CH}_{4}$ production while improving soil fertility and contributing towards the sustainability of the system, the present study was carried out with the objective of evaluating the yield and nutritional composition of forage, as well as in vitro gas production of corn silages intercropped with palisade grass and pigeon pea.

\section{Materials and Methods}

\subsection{Field Trial Characterization}

The field trial was conducted at Instituto Federal Goiano-Campus Iporá $\left(16^{\circ} 25^{\prime} 29^{\prime \prime} \mathrm{S}\right.$ and $51^{\circ} 09^{\prime} 04^{\prime \prime} \mathrm{W}, 602 \mathrm{msl}$ of altitude), during 2016 and 2017. The main climate in the region is Aw type (tropical, with mild dry winter and hot and rainy summer), with average temperature of $24.4{ }^{\circ} \mathrm{C}$ and mean annual precipitation of $1613 \mathrm{~mm}$ [29]. The soil at the experimental area is classified as Cambisoil (World Reference Base for Soil Resources) [30], and Inceptisols (US soil taxonomy) USDA [31]. Soil chemical composition (0-20 cm depth) before 2016/2017 crop season was pH 5.2, Al $0.0 \mathrm{cmol}_{\mathrm{C}}$ $\mathrm{dm}^{-3}, \mathrm{Ca} 2.7 \mathrm{cmol}_{\mathrm{C}} \mathrm{dm}^{-3}, \mathrm{Mg} 1.5 \mathrm{cmol}_{\mathrm{c}} \mathrm{dm}^{-3}, \mathrm{H}+\mathrm{Al} 2.5 \mathrm{cmol}_{\mathrm{C}} \mathrm{dm}^{-3}, \mathrm{P} 2.0 \mathrm{mg} \mathrm{dm}^{-3}, \mathrm{~K} 148 \mathrm{mg} \mathrm{dm}^{-3}$, Base saturation $64 \%$, and aluminum saturation $0 \%$. The soil texture was $56 \%$ Sand, $17 \%$ Silt, $27 \%$ Clay, classifying as Sandy clay loam according to USDA [31].

The intercropping of corn (Zea mays) with palisade grass (Brachiaria syn. Urochloa brizantha cv. BRS Xaraés) and pigeon pea (Cajanus cajan cv. Super N) was sowed equally in the experimental area on 23 November 2016 using a multi-seed drill. Corn (Biomatrix hybrid-BM 840 ${ }^{\circledR}$ ) was sown in $0.8 \mathrm{~m}$ spaced rows at 60,000 seeds.ha ${ }^{-1}$. Simultaneously, pigeon pea was sown in $0.8 \mathrm{~m}$ spaced rows intercalated with corn rows at 180,000 seeds.ha ${ }^{-1}$. Palisade grass was sown in soil surface with the small seeds distribution system at the rate of 360,000 seeds.ha $^{-1}$ ( $4 \mathrm{~kg}$ of viable seeds.ha ${ }^{-1}$ ) (Figure 1). 

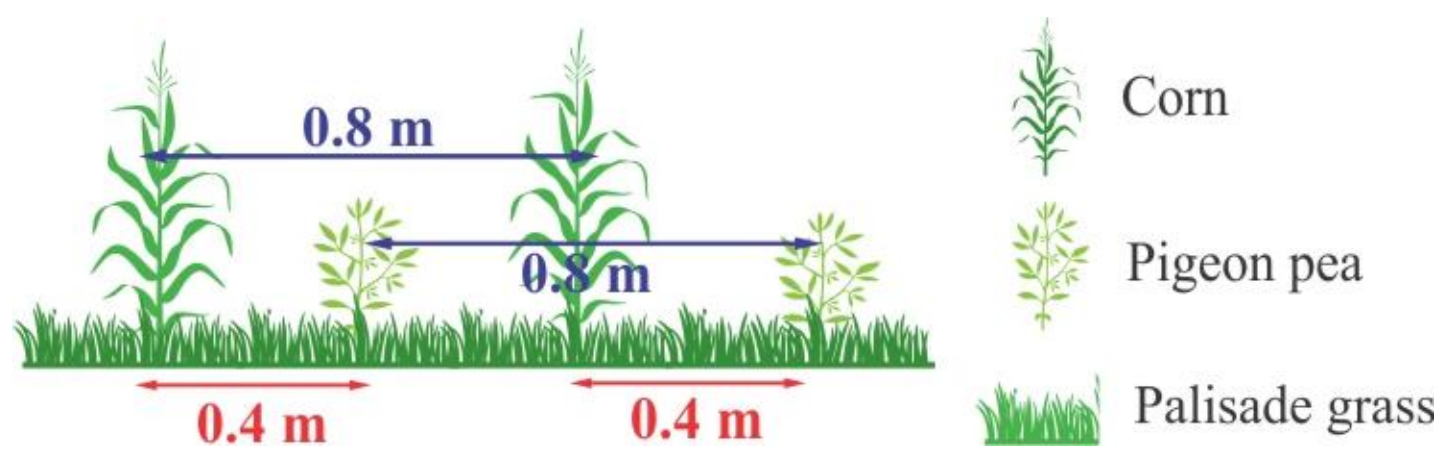

Figure 1. Scheme showing the disposition of the three species in the intercropping system.

The fertilization was performed with $310 \mathrm{~kg}$ of simple superphosphate $\left(18 \%\right.$ of $\left.\mathrm{P}_{2} \mathrm{O}_{5}\right)$ in seeding rows with the seed drill. At V4 corn stage, $250 \mathrm{~kg}$ of urea.ha ${ }^{-1}\left(112.5 \mathrm{~kg}\right.$ of N.ha $\left.{ }^{-1}\right)$ were applied superficially. It was not necessary to use herbicide or insecticides after sowing.

\subsection{Forage Harvest}

At 94 days after sowing (25 February 2017), forage was sampled in fifty-four random points in experimental area. Harvesting point was determined by the optimum point for corn ensilage, 30 to $35 \%$ of dry matter content [32]. Forage was cut at $0.1 \mathrm{~m}$ from soil surface.

At each sampling point, we collected $1 \mathrm{~m}^{2}$ of corn-exclusive sample and other $1 \mathrm{~m}^{2}$ of total forage sample with the three species intercropped. Both samples were ground into $1 \mathrm{~cm}$ particles size and compacted in micro-silos (PVC tubes with $10 \mathrm{~cm}$ of diameter and $40 \mathrm{~cm}$ of length with PVC caps in both sides). At the same site, we collected two samples for estimation of dry matter content and chemical composition analyses. One sample of $1 \mathrm{~m}^{2}$ sample $1 \mathrm{~m}^{2}$ was evaluated for total forage availability (three species intercropped) and the other sample was stratified on each forage species (Figure 2).

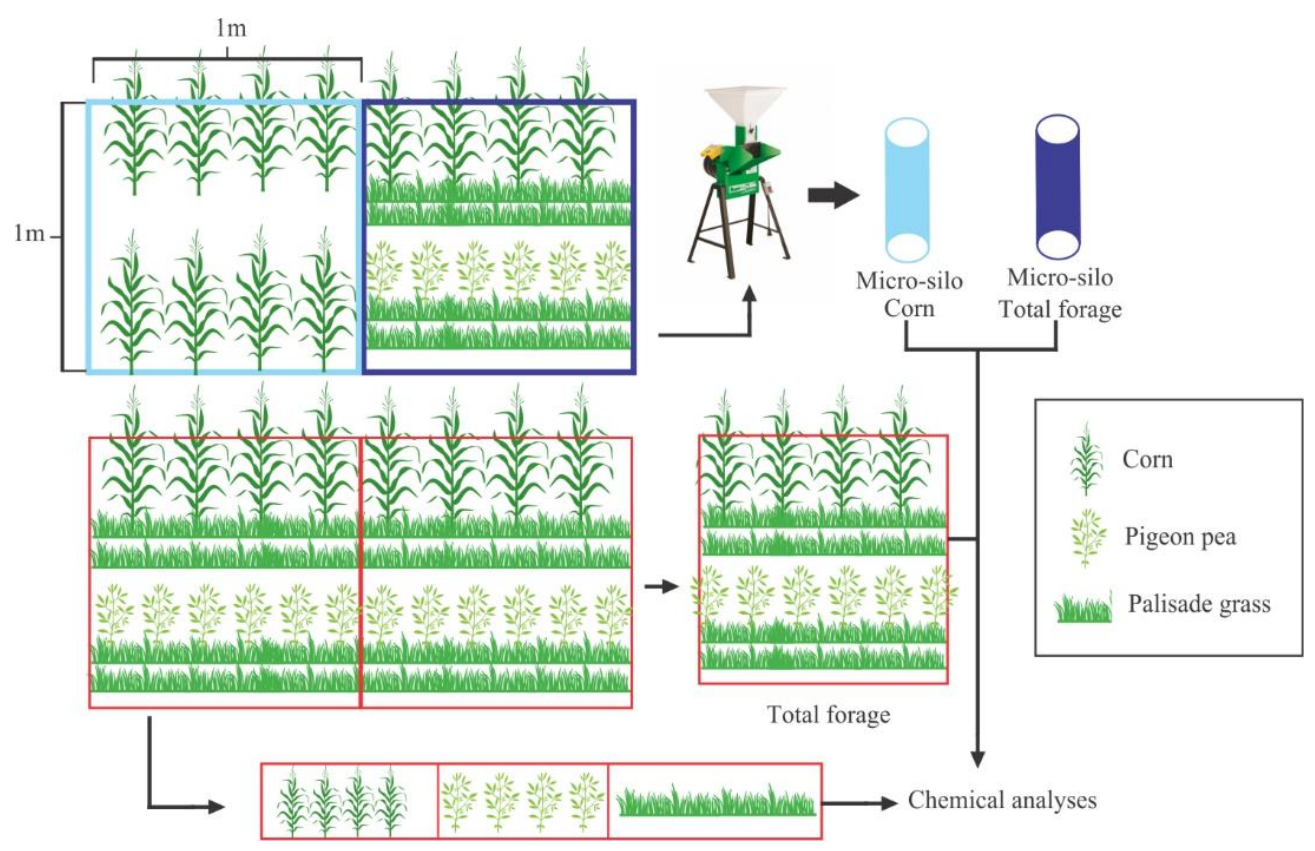

Figure 2. Scheme showing the sampling process and the composition of the two micro-silos.

After 100 days of ensilage, the 108 micro-silos (54 of corn-exclusive silage and 54 of total intercropped silage) were opened, and one sample from each micro-silo was collected for chemical composition analyses and in vitro gas production trial. The top $10 \mathrm{~cm}$ of the micro-silo was discarded. 
Central material was homogenized and sampled. Samples were dried at $65^{\circ} \mathrm{C}$ for $48 \mathrm{~h}$ and ground at $1 \mathrm{~mm}$. Chemical composition analyses determined: dry matter (DM; ID n. 934.01), crude protein (CP; ID n. 2001.11), and ashes (ID no. 942.05), according to AOAC [33] methods; neutral detergent fiber (NDF), acid detergent fiber (ADF), and lignin content were determined according to Van Soest [34], adapted by Mertens [35]. Filter bags (F57, Ankom Macedon, NY, USA) were used in a fiber analyzer (Tecnal, Piracicaba, Brazil). All analyses were carried out at the Animal Nutrition Laboratory (LANA) of Centro de Energia Nuclear na Agricultura from Universidade de São Paulo (CENA/USP).

\subsection{In Vitro Gas Production Assay}

Samples from exclusive corn silage and total forage (three species intercropped) were used for in vitro gas production assay. Inocula preparation was carried out using ruminal content from four adult rumen-cannulated Santa Inês male sheep (CENA ethical Commission on use of animals in experimentation protocol number 011/2016) (averaging $60 \pm 2.7 \mathrm{~kg}$ of body weight) collected before the morning feed. The animals were fed ad libitum tropical grass hay (Tifton 85-Cynodon spp.) and ruminal content samples of each animal were collected into individual thermal containers on a 50:50 liquid and solid fraction ratio (volume basis) [36] and were combined between themselves to form two different inocula solutions, each one made of rumen fluid from two different animals. The incubation was performed in duplicates (each sample incubated with each one of the inocula) according to procedures described by Theodorou et al. [37] and Mauricio et al. [38], with adaptations from Bueno et al. [36] and Longo et al. [39].

Half gram $(0.5 \mathrm{~g})$ of ground $(1 \mathrm{~mm})$ silage sample was weighed into Ankom filter bags (Ankom F-57, Macedon, NY, USA), transferred into $160 \mathrm{~mL}$ glass bottles together with $50 \mathrm{~mL}$ of incubation medium (Menke's buffered medium) and $25 \mathrm{~mL}$ of inoculum, allowing $85 \mathrm{~mL}$ of headspace in each flask. Blank flasks (without substrate) to calculate net gas production and laboratorial standard samples were also included in the assay. Afterwards, bottles were sealed, agitated and incubated in a forced ventilation oven at $39^{\circ} \mathrm{C}$ for $24 \mathrm{~h}$. Pressure inside of each bottle was measured at $0,2,4,8,12$, and $24 \mathrm{~h}$ after starting the incubation using a pressure transducer and data logger (Pressure Press Data 800, LANA, CENA/USP, Piracicaba, Brazil) to calculate total gas production based on the equation $\mathrm{V}=(5.96 \times \mathrm{p})-0.89$, where: $\mathrm{V}=$ gas volume $(\mathrm{mL}) ; \mathrm{p}=$ measured pressure $(\mathrm{psi})$.

During each pressure measurement procedure (except at $0 \mathrm{~h}$ ), $2 \mathrm{~mL}$ gas samples were collected from each bottle into $10 \mathrm{~mL}$ evacuated tubes by using $5 \mathrm{~mL}$ syringes (Becton-Dickson Indústria Cirúrgica Ltda, Curitiba, Brazil) for determination of $\mathrm{CH}_{4}$ concentration in a gas chromatograph (Shimadzu GC-2010, Tokyo, Japan) equipped with flame ionization detector (FID) and a capillary HP-Molesieve column (GC $30 \mathrm{~m} \times 0.53 \mathrm{~mm} \times 25 \mu \mathrm{m}$ ), employing chromatographic conditions as described by Lima et al. [40].

At the end of incubation, bags were removed from the bottles and put into cold water $\left(4{ }^{\circ} \mathrm{C}\right)$ to cease the microbial fermentation process. Bags were treated with neutral detergent solution for $1 \mathrm{~h}$ at $39^{\circ} \mathrm{C}$, washed with water, then dried in a forced ventilation oven for $16 \mathrm{~h}$ at $105^{\circ} \mathrm{C}$ and then taken to a muffle furnace at $550^{\circ} \mathrm{C}$ for $4 \mathrm{~h}$ in order to determine truly degraded organic matter (TDOM), which was calculated as the difference between incubated organic matter $(\mathrm{OM})$ and remaining undegraded $\mathrm{OM}$. The partition factor $(\mathrm{PF})$ was used to estimate microbial efficiency through the relationship between $\operatorname{TDOM}(\mathrm{mg})$ and total gas production $(\mathrm{mL})$ according to Blümmel et al. [41].

\subsection{Statistical Analyses}

In vitro gas production data was corrected for inoculum effect using a linear model within lme4 package [42] in software R [43]. Bromatological and gas production corrected data was submitted to analyses of variance (ANOVA) using the "lm" and "Anova" function of "car" package [44] in software R (https://www.r-project.org/) [43] and the least square means were calculated with "emmeans" function of the "emmeans" package [45]. Regression analyses were performed to obtain the best predictive model for forage yield, using the plant densities as independent variables. The regressions used the 
" $\mathrm{lm}$ " function with "anova" to verify the significance of the effects and we used the Akaike information criterion (AIC) and Schwarz Bayesian criterion (BIC) as selection criteria to define the best model.

Principal component analyses (PCA) were done to better comprehend the relation between the variables. "FactoMineR" [46] and "factoextra" [47] packages were used in software R for PCA analyses. We used the "dimdesc" function to point out the variables that better describe the dimension using a significance threshold of 0.05 . The Pearson correlation analyses used the "Hmisc" package [48].

To provide a more accurate overview about the relationship between the plant population, forage yield, bromatological composition and in vitro gas production, we performed four path models with confirmatory factor analyses ("cfa" function in "lavaan" package) [49]. We used the "semPaths" function of "semPlot" package [50] for plotting path models. We plotted all results showed here using "ggpubr" [51] and "ggplot2" [52] packages in software R [43].

A confirmatory factor analysis (CFA) is a type of structural equation modeling that deals specifically with the relationships between observed measures or indicators and latent variables or factors. It is used to test whether the data fit a hypothesized measurement model. The goal of latent variable measurement models (i.e., factor analysis) is to establish the number and nature of factors that account for the variation and covariation among a set of indicators. The observed measures are intercorrelated because they share a common cause (i.e., they are influenced by the same underlying construct); if the latent construct was partialled out, the intercorrelations among the observed measures would be zero. Thus, a measurement model such as CFA provides a more parsimonious understanding of the covariation among a set of indicators because the number of factors is less than the number of measured variables. More information about structural equation modeling and confirmatory factor analysis can be obtained in Schreiber et al. [53].

\section{Results}

Intercropped silage (corn, pigeon pea, and palisade grass) had higher $\mathrm{CP}, \mathrm{ADF}$, and lignin (Table 1) than exclusive corn silage. Corn, palisade grass, and pigeon pea forage presented $6.2 \pm 1.63 \%$, $7.8 \pm 0.21 \%$, and $17.3 \pm 0.73 \%$ of $\mathrm{CP}$, respectively. Therefore, both intercropped species can contribute to increase $\mathrm{CP}$ of total forage, specially pigeon pea. Descriptive statistics of all data used are shown in supplementary material (Table S1).

Table 1. Nutritional composition (g. $\mathrm{kg}^{-1}$ of dry matter) of silages with only corn and intercropping of corn, pigeon pea (PP) and palisade grass (Brachiaria brizantha- $\mathrm{Bb})$ (mean \pm standard error).

\begin{tabular}{cccc}
\hline & Corn & Corn $+\mathbf{P P}+\mathbf{B b}$ & $p$-Value \\
\hline Ash & $50.4 \pm 1.05$ & $52.6 \pm 0.61$ & 0.078 \\
Crude Protein & $\mathbf{5 9 . 9} \pm \mathbf{2 . 8 8}$ & $\mathbf{6 9 . 1} \pm \mathbf{1 . 4 3}$ & $\mathbf{0 . 0 0 6}$ \\
Neutral detergent fiber & $521 \pm 9.97$ & $543 \pm 5.76$ & 0.069 \\
Acid detergent fiber & $\mathbf{2 9 5} \pm \mathbf{6 . 6 6}$ & $\mathbf{3 3 0} \pm 3.85$ & $\mathbf{< 0 . 0 0 1}$ \\
Lignin & $\mathbf{3 3 . 3} \pm \mathbf{2 . 3 9}$ & $\mathbf{4 5 . 9} \pm \mathbf{1 . 3 8}$ & $\mathbf{< 0 . 0 0 1}$ \\
\hline
\end{tabular}

Significant $p$-value $(<0.05)$ highlighted in bold.

Intercropped silage produced $24.3 \%$ less $\mathrm{CH}_{4}$ per unit of incubated dry matter and $29.0 \%$ less $\mathrm{CH}_{4}$ per degradable organic matter compared to exclusive corn silage (Table 2). Total gas production per degradable organic matter was reduced by $14.2 \%$ in intercropped silage when compared to corn silage. Moreover, degradability of organic matter (DOM) decreased by $5.5 \%$ when palisade grass and pigeon pea were included in the silage. At the same time, $\mathrm{CH}_{4}$ proportion in total produced gases was $7.4 \%$ in corn silage and $6.3 \%$ in intercropped silage (Table 2). Therefore, intercropped silage decreased $\mathrm{CH}_{4}$ production in greater proportion than reduced total gas production and DOM when compared with corn-exclusive silage. 
Table 2. In vitro gas production (mean \pm standard error) of exclusive corn silage and silage from intercropping of corn, pigeon pea (PP) and palisade grass (Brachiaria brizantha-Bb).

\begin{tabular}{cccc}
\hline & Corn & Corn + PP + Bb & $p$-Value \\
\hline GP-DM & $\mathbf{7 6 . 4} \pm \mathbf{1 . 4 4}$ & $\mathbf{6 9 . 4} \pm \mathbf{0 . 8 3}$ & $<0.001$ \\
$\mathrm{CH}_{4}$-DM & $\mathbf{5 . 7 3} \pm \mathbf{0 . 2 2}$ & $4.34 \pm \mathbf{0 . 1 3}$ & $<0.001$ \\
DOM & $\mathbf{4 2 2} \pm 5.95$ & $399 \pm 3.44$ & $\mathbf{0 . 0 0 1}$ \\
$\mathrm{GP}-\mathrm{DOM}$ & $\mathbf{3 2 . 3} \pm \mathbf{0 . 9 7}$ & $\mathbf{2 7 . 7} \pm \mathbf{0 . 5 6}$ & $<0.001$ \\
$\mathrm{CH}_{4}$-DOM & $\mathbf{2 . 4 5} \pm \mathbf{0 . 1 0}$ & $\mathbf{1 . 7 4} \pm \mathbf{0 . 0 6}$ & $<0.001$ \\
PF & $4.87 \pm 0.10$ & $4.99 \pm 0.06$ & 0.301 \\
\hline
\end{tabular}

Significant $p$-value $(<0.05)$ highlighted in bold. GP-DM: Total gas production per dry matter $\left(\mathrm{mL}^{-\mathrm{g}^{-1}}\right) ; \mathrm{CH}_{4}$-DM: Methane production per dry matter $\left(\mathrm{mL}^{-\mathrm{g}^{-1}}\right)$; DOM: Organic matter degradability $\left(\mathrm{g} \cdot \mathrm{kg}^{-1}\right)$; GP-DOM: Total gas production per degraded organic matter $\left(\mathrm{mL} \cdot \mathrm{g}^{-1}\right) ; \mathrm{CH}_{4}-\mathrm{DOM}$ : Methane production per degraded organic matter $\left(\mathrm{mL}^{-1}\right)$; PF: Partition factor (g of degraded organic matter/mL of produced gas).

Further, we performed a PCA analyses to evaluate the relationship between measurements in three intercropped species. Based on the proportion of the variance explained by each dimension (Figure S1), we evaluated the first four dimensions (Figure 3). The first dimension showed negative relationship between the palisade grass population and DM production with the corn DM production, gas production per organic matter, and DOM (Figure 3 and Figure S2). The second dimension highlighted the negative relationship between NDF and ADF in pigeon pea forage with pigeon pea DM production and crude protein content. Therefore, higher pigeon pea DM production with higher protein content decreased the NDF and ADF content in pigeon pea.

The in vitro gas production variables showed significant contribution (Figure S3) and correlation (Figure 3) with the first and third dimension. The first dimension showed that corn dry matter proportion increased the gas and $\mathrm{CH}_{4}$ production per degradable organic matter with simultaneous increase on DOM. The third dimension showed that total gas production (per dry matter and per organic matter) increase together with DOM and palisade grass proportion in DM of total forage. These variables were opposed mainly to Lignin level in total silage, pigeon pea population, DM production and proportion in DM (Figure 3). The quality of representation for variables on the 10 dimensions are showed in supplementary material Figure S4.

The results of correlation analyses (Figure 4) showed similar pattern observed previously in PCA results. The pigeon pea population and proportion in dry matter showed positive and significant correlation with the crude protein and lignin of the silage. The palisade grass population and proportion in dry matter showed positive and significant correlation with NDF in total silage.

The Path analysis evaluating the components of intercropping effects on total forage yield (Figure 5) showed that corn dry matter production was the main determinant of the total forage yield. Moreover, the palisade grass dry matter production had no effect on total forage yield. Covariances between the population of the species in the intercropping was close to zero, demonstrating no effect between them. 


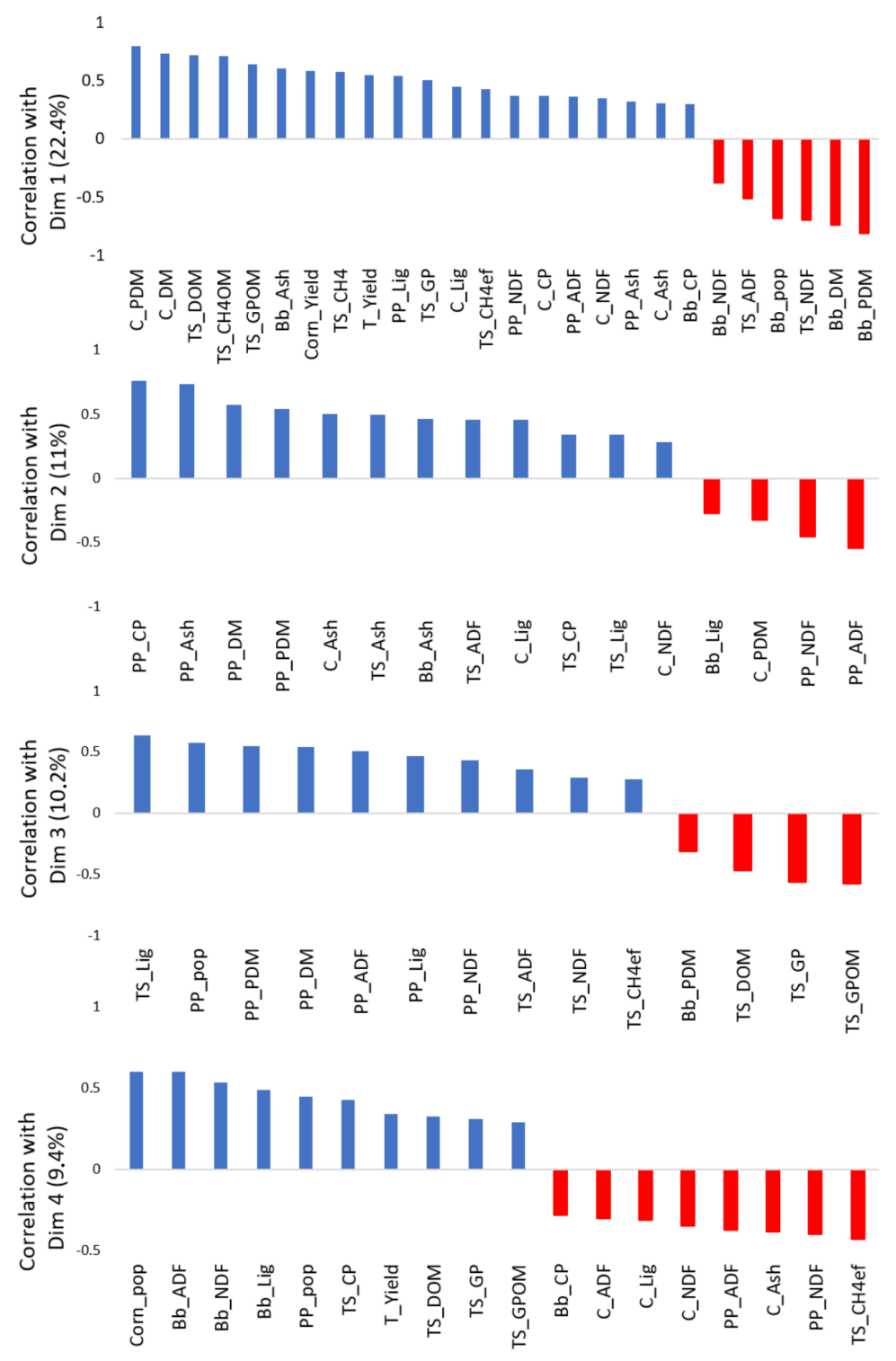

Figure 3. Correlation coefficients between each variable and the first four dimensions of principal component analysis using the "dimdesc" function of "FactoMineR" package (significance threshold $=0.05$ ). The proportions of variance explained by each dimension are shown between parenthesis in $y$ axis label. Bb_ADF: Acid detergent fiber of palisade grass; Bb_Ash: Ash of palisade grass; $\mathrm{Bb} \_\mathrm{CP}$ : Crude protein of palisade grass; Bb_DM: Dry matter of palisade grass; Bb_Lig: Lignin of palisade grass; Bb_NDF: Neutral Detergent Fiber of palisade grass; Bb_PDM: Proportion of dry matter of palisade grass; Bb_pop: Population of palisade grass; C_ADF: Acid Detergent Fiber of corn; C_Ash: Ash of corn; C_CP: Crude protein of corn; C_DM: Dry matter of corn; C_Lig: Lignin of corn; C_NDF: Neutral Detergent Fiber of corn; C_PDM: Proportion of dry matter of corn; Corn_pop: Population of corn; Corn_Yield: Yield of corn; PP_ADF: Acid detergent fiber of pigeon pea; PP_Ash: Ash of pigeon pea; PP_CP: Crude protein of pigeon pea; PP_DM: Dry matter of pigeon pea; PP_Lig: Lignin of pigeon pea; PP_NDF: Neutral Detergent Fiber of pigeon pea; PP_PDM: Proportion of dry matter of pigeon pea; PP_pop: Population of pigeon pea; T_Yield: Total forage yield; TS_ADF: Acid detergent fiber in total forage silage; TS_Ash: Ash in total forage silage; $\mathrm{TS}_{-} \mathrm{CH}_{4}$ : Methane production in total forage silage; TS_; TS_ $\mathrm{CH}_{4} \mathrm{OM}$ : Methane production per organic matter in total forage silage; TS_CP: Total gas production in total forage silage; TS_DOM: Organic matter in total forage silage; TS_GP: Total gas production in total forage silage; TS_GPOM: Total gas production per organic matter in total forage silage; TS_Lig: Lignin in total forage silage; TS_NDF: Neutral Detergent Fiber in total forage silage. 


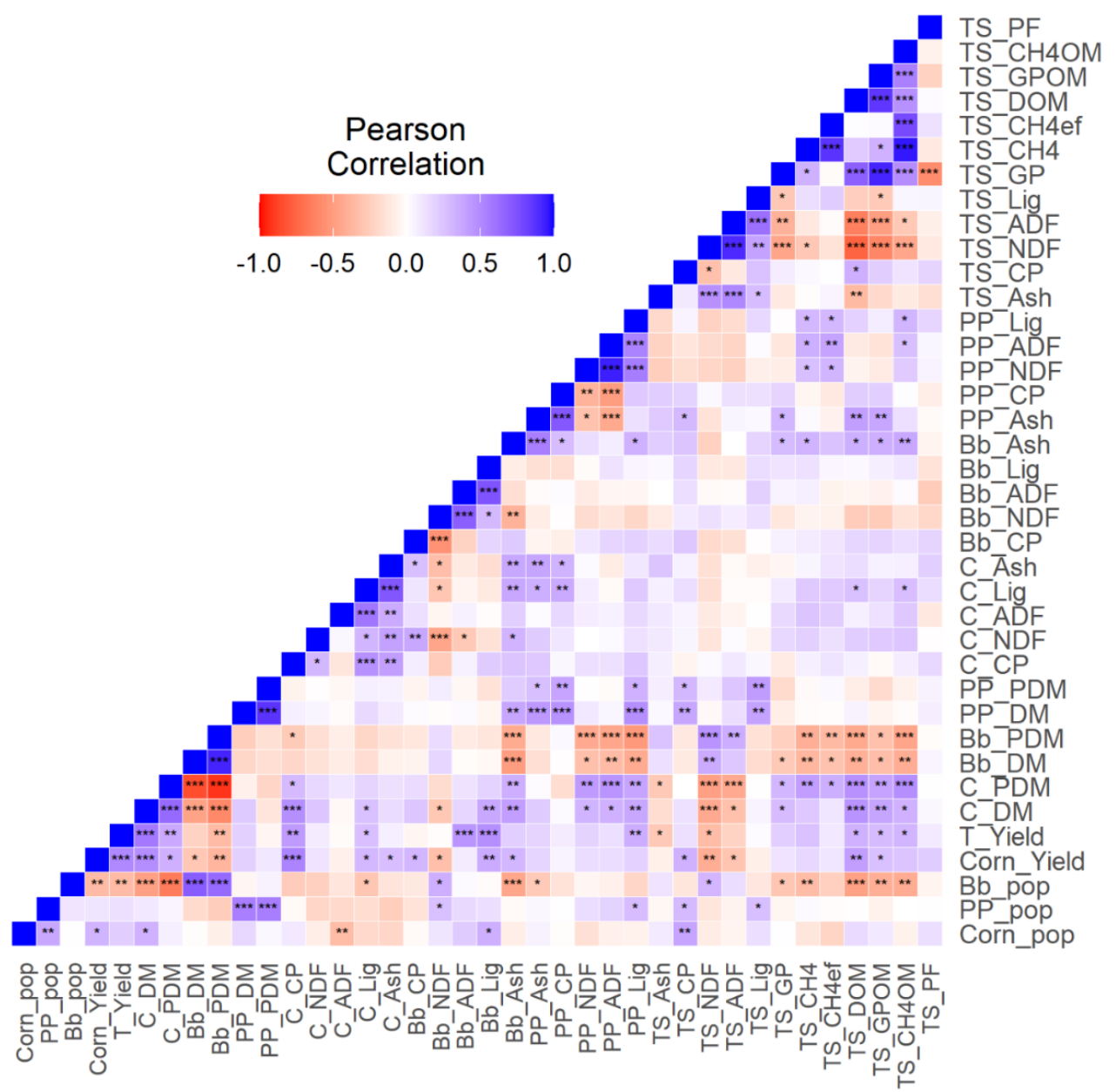

Figure 4. Correlation between variables of dry matter production, chemical composition of each species of intercropping system, chemical composition of silage produced by intercropping and in vitro gas production $\left(*: p<0.05 ;{ }^{* *}: p<0.01 ; * * *: p<0.001\right)$. Bb_ADF: Acid detergent fiber of palisade grass; Bb_Ash: Ash of palisade grass; Bb_CP: Crude protein of palisade grass; Bb_DM: Dry matter of palisade grass; Bb_Lig: Lignin of palisade grass; Bb_NDF: Neutral Detergent Fiber of palisade grass; Bb_PDM: Proportion of dry matter of palisade grass; Bb_pop: Population of palisade grass; C_ADF: Acid Detergent Fiber of corn; C_Ash: Ash of corn; C_CP: Crude protein of corn; C_DM: Dry matter of corn; C_Lig: Lignin of corn; C_NDF: Neutral Detergent Fiber of corn; C_PDM: Proportion of dry matter of corn; Corn_pop: Population of corn; Corn_Yield: Yield of corn; PP_ADF: Acid detergent fiber of pigeon pea; PP_Ash: Ash of pigeon pea; PP_CP: Crude protein of pigeon pea; PP_DM: Dry matter of pigeon pea; PP_Lig: Lignin of pigeon pea; PP_NDF: Neutral Detergent Fiber of pigeon pea; PP_PDM: Proportion of dry matter of pigeon pea; T_Yield: Total forage yield; TS_ADF: Acid detergent fiber in total forage silage; TS_Ash: Ash in total forage silage; $\mathrm{TS}_{-} \mathrm{CH}_{4}$ : Methane production in total forage silage; TS_CH 4 OM: Methane production per organic matter in total forage silage; TS_CP: Total gas production in total forage silage; TS_DOM: Organic matter in total forage silage; TS_GP: Total gas production in total forage silage; TS_GPOM: Total gas production per organic matter in total forage silage; TS_Lig: Lignin in total forage silage;TS_NDF: Neutral Detergent Fiber in total forage silage; TS_PF: Partition fator (g of degradaded organic matter/mL of produced gas) in total forage silage. 


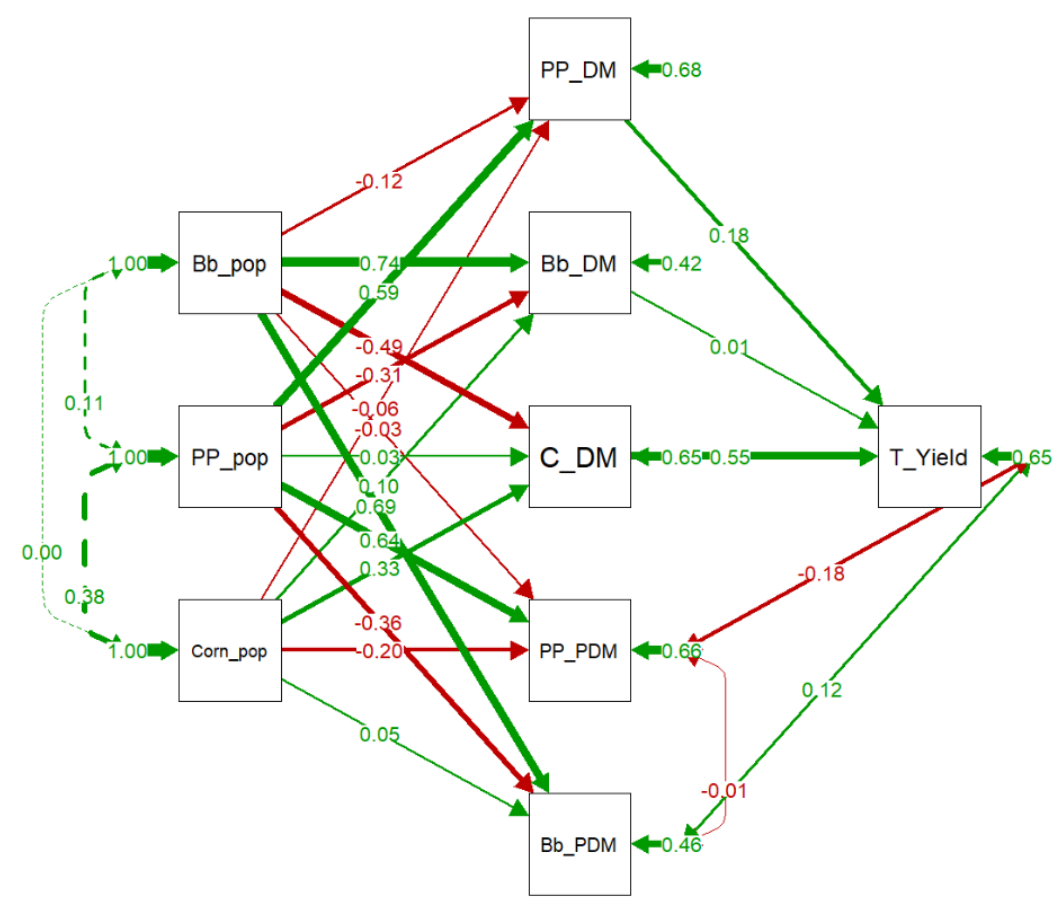

Figure 5. Path Diagram of the confirmatory factor analysis (CFA) evaluating the effect of the population of each component on dry matter production of each component and its contribution on the total forage yield of the intercropping system. Green and red arrows indicate positive and negative regression/covariance coefficients, respectively. Arrows thickness are proportional to the value of the regression/covariance coefficients. Bb_DM: Dry matter of palisade grass; Bb_PDM: Proportion of dry matter of palisade grass; Bb_pop: Population of palisade grass; C_DM: Dry matter of corn; Corn_pop: Population of corn; PP_DM: Dry matter of pigeon pea; PP_PDM: Proportion of dry matter of pigeon pea; PP_pop: Population of pigeon pea; T_Yield: Total forage yield.

The main effect of the proportion of pigeon pea in silage DM was the increase in CP, ADF, and lignin content (Figure 6). The increase palisade grass proportion in silage DM led to higher ashes, NDF and ADF contents in the silage (Figure 6). Increased proportion of palisade grass in silage DM had negative effect on all in vitro gas production variables, except partition factor (Figure 7). Pigeon pea proportion in dry matter had weak negative effect on in vitro gas production and degradability of organic matter.

Other path model evaluated the effect of nutritional composition of each intercropped species on chemical composition of silage and its relation with gas production variables (Figure 8). Palisade grass $\mathrm{CP}$ had a positive relationship with $\mathrm{CP}$ of the silage. The NDF of the silage had significant negative effect in gas production and degradability of organic matter (Figure 8).

Regression analyses yielded few significant results. Pigeon pea had positive linear regression with total silage $\mathrm{CP}$ and quadratic relationship with total silage lignin (Figure S5). Palisade grass population had a positive linear regression with total silage NDF and ADF (Figure S6). 


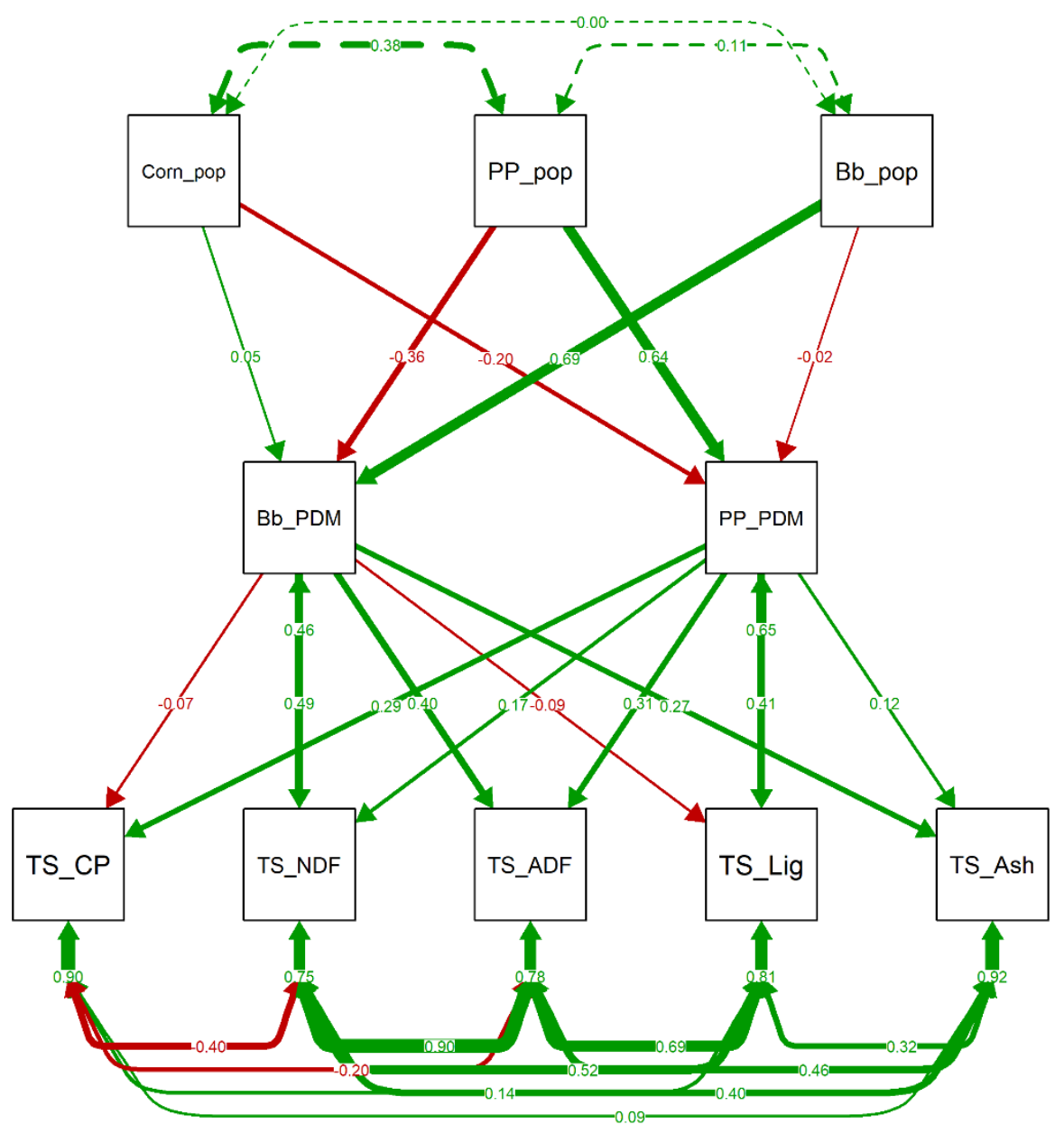

Figure 6. Path Diagram of the confirmatory factor analyses (CFA) results evaluating the effect of the population and dry matter production of each component of the intercropping system on the nutritional composition of the silage. Green and red arrows indicate positive and negative regression/covariance coefficients, respectively. Arrows thickness are proportional to the value of the regression/covariance coefficients. Bb_PDM: Proportion of dry matter of palisade grass; Bb_pop: Population of palisade grass; Corn_pop: Population of corn; PP_PDM: Proportion of dry matter of pigeon pea; PP_pop: Population of pigeon pea; TS_ADF: Acid detergent fiber in total forage silage; TS_Ash: Ash in total forage silage; TS_CP: Total gas production in total forage silage; TS_Lig: Lignin in total forage silage; TS_NDF: Neutral Detergent Fiber in total forage silage. 


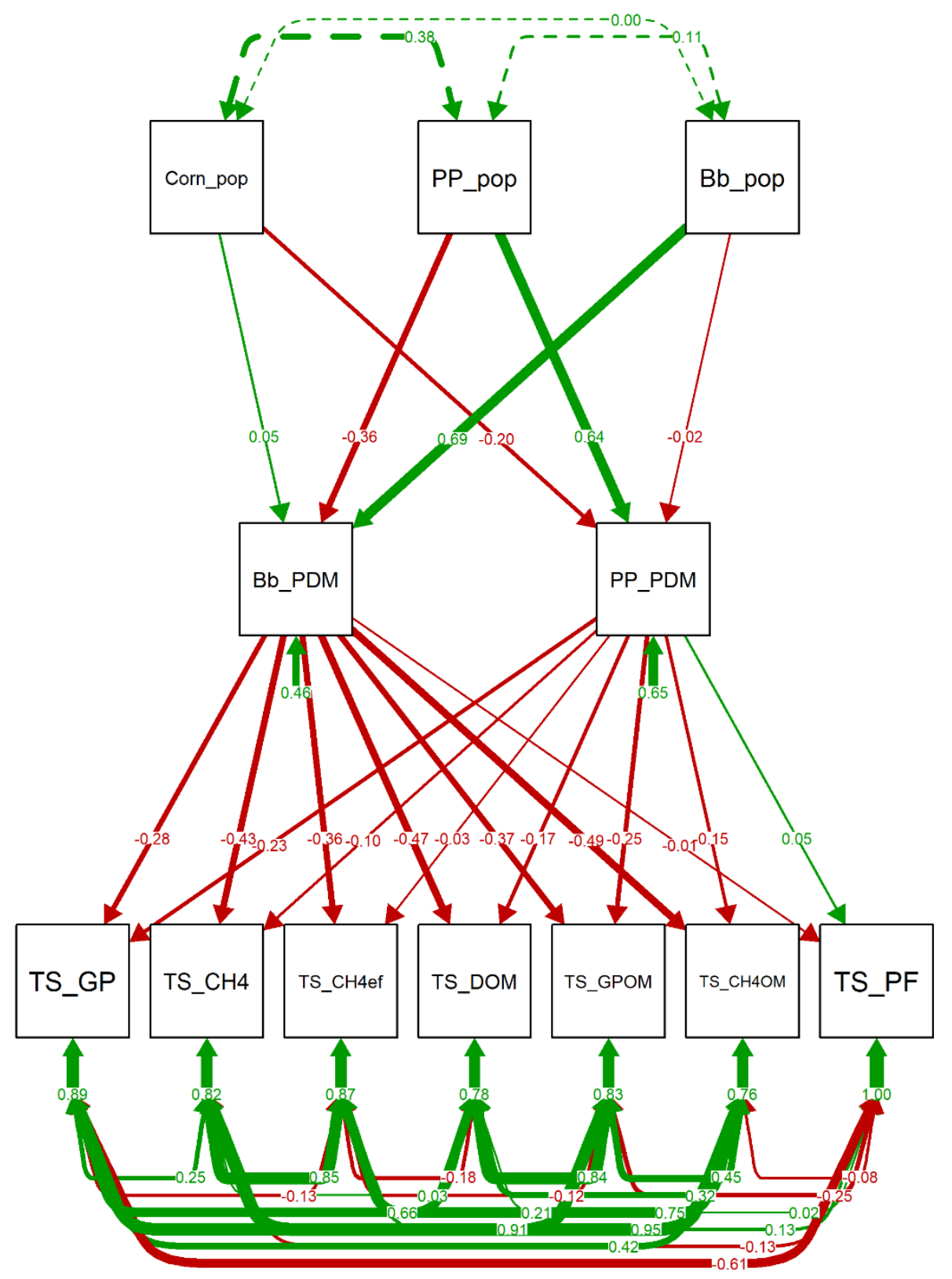

Figure 7. Path Diagram of the confirmatory factor analysis (CFA) evaluating the effect of the population and dry matter production of each component of the intercropping system on in vitro gas production of silage. Green and red arrows indicate positive and negative regression/covariance coefficients, respectively. Arrows thickness are proportional to the value of the regression/covariance coefficients. Bb_PDM: Proportion of dry matter of palisade grass; Bb_pop: Population of palisade grass; Corn_pop: Population of corn; PP_PDM: Proportion of dry matter of pigeon pea; PP_pop: Population of pigeon pea; TS_CH${ }_{4}$ : Methane production in total forage silage; TS_; $\mathrm{TS}_{-} \mathrm{CH}_{4} \mathrm{OM}$ : Methane production per organic matter in total forage silage; TS_DOM: Organic matter in total forage silage; TS_GP: Total gas production in total forage silage; TS_GPOM: Total gas production per organic matter in total forage silage. 


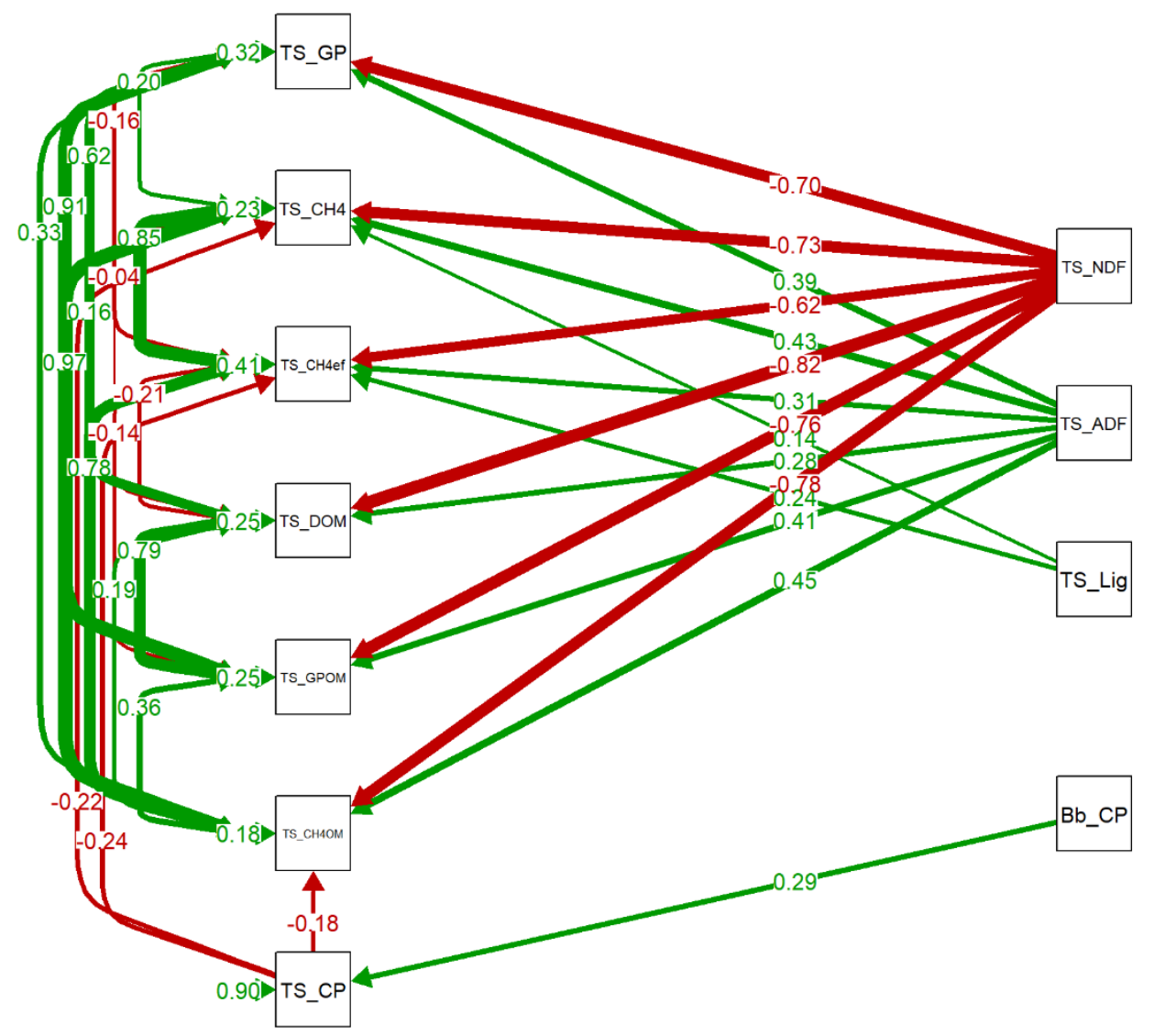

Figure 8. Path Diagram of the confirmatory factor analysis (CFA) evaluating the effect of nutritional content of each component of the intercropping system into the nutritional composition of the silage and its effect into the in vitro gas production. Only significant $(p<0.05)$ regressions/covariances (arrows) are shown. Bb_CP: Crude protein of palisade grass; TS_ADF: Acid detergent fiber in total forage silage; TS_Ash: Ash in total forage silage; $\mathrm{TS}_{-} \mathrm{CH}_{4}$ : Methane production in total forage silage; TS_; TS_CH $\mathrm{CH}_{4} \mathrm{OM}$ : Methane production per organic matter in total forage silage; TS_CP: Total gas production in total forage silage; TS_DOM: Organic matter in total forage silage; TS_GP: Total gas production in total forage silage; TS_GPOM: Total gas production per organic matter in total forage silage; TS_Lig: Lignin in total forage silage; TS_NDF: Neutral Detergent Fiber in total forage silage; TS_PF: Partition fator (g of degraded organic matter/mL of produced gas) in total forage silage.

\section{Discussion}

\subsection{Total Dry Matter Production}

Seeding method of the corn and intercropped forage species can determine the competition degree between species [54]. Efficiency of solar radiation utilization is one of the main factors affecting plant growth [55], especially in intercropped systems, where there is a high resource competition. Thus, agricultural system parameters such as seeding density and row spacing can affect forage yield [56].

In PCA first dimension (Figure 3), palisade grass DM is in opposition to corn DM. However, in path analyses (Figure 5), the correlation between the populations was zero. Therefore, the negative relationship in DM production is not associated with competition between the species, which would lead to population reduction for one of the components. Probably, this inverse relationship in DM production is related to spatial variability, where corn did not grow, the palisade grass filled the gap and increased their growth, which guaranteed the forage production of the system. It is well known that the corn and palisade grass intercropping, properly managed, did not impair corn growth [57-59]. 
Makino et al. [60] evaluated light interception and corn yield in two rows spacing ( 0.45 and $0.90 \mathrm{~m})$ of corn intercropped with palisade grass and concluded that the seeding arranges had higher impact on yield than the palisade grass. Reduced row spacing promotes better solar radiation utilization and increased corn yield. Therefore, in the present study, palisade grass population in intercropping did not decrease corn population (Figure 5) and contributed to maintenance of forage production where corn was not able to grow properly, sustaining the final silage yield of the field. Similar results were reported by Souza et al. [61].

\subsection{Bromatological Quality of Intercropped Silage}

One of the goals in legume-grass intercropping is to increase silage crude protein $[62,63]$. Our intercropped silage had higher crude protein (Table 1) and this parameter had positive correlation with pigeon pea forage proportion in DM (Figure 4). The increase in silage CP can be explained by the $\mathrm{CP}$ content in pigeon pea forage, which was $17.3 \%$ in this study (Table S1) and can reach up to $27 \%$ of CP [64,65]. Stella et al. [66] reported a linear increase in CP with soybean enrichment in corn and sorghum ensilage. Therefore, the legume intercropping allows to change the concentrate/roughage in the diet, reducing feeding cost because of lower addition of external protein inputs [67].

Pigeon pea proportion in total forage DM increased mainly CP, ADF, and lignin in total silage (Figure 6). Pereira et al. [68], evaluating the addition of pigeon pea in sugar cane silage, reported similar results: increased $\mathrm{CP}, \mathrm{ADF}$, and lignin in final silage. Acid detergent fiber is closely-related to digestibility, as it represents lignin and cellulose content [69].

The PCA and path analyses indicated that NDF and ADF increase was related to palisade grass proportion in total forage DM (Figures 3 and 6). Fiber measures (NDF and ADF) and palisade grass proportion in total DM had a negative correlation with $\mathrm{CP}$ in total silage (Figure 6). The intercropped grass modifies its physiology in a reduced light environment, which promotes leaf and stem elongation in the search for light [70]. This process leads to lignin deposition, and consequently higher ADF, to maintain plant hardness with an elongated stem [71,72].

In addition, the intercropped silage can promote several agronomic benefits in the area, such as diversification of straw for no till system [73], reduced pest infestation [74], improved soil nutrient cycling [75] and consequently decreased production costs [76]. Moreover, the deep root system together with symbiosis with $\mathrm{N}$ fixing bacteria, allows the intercropped legume to supply significant amounts of nitrogen to soil-plant system [77-79].

\subsection{In Vitro Gas Production}

High-quality forages can decrease the $\mathrm{CH}_{4}$ production changing the fermentation route due to increased contents of easy fermentable carbohydrates which have higher degradability and passage rate [80]. In general, forages have higher structural carbohydrates, and their ruminal fermentation favors methanogenic microorganisms development, leading into higher activity of cellulolytic and saccharolytic bacteria [81,82]. Thus, fermentation of tropical grasses usually promotes the increase in $\mathrm{CH}_{4}$ production [83]. However, high-starch and protein diets promote development of amylolytic and proteolytic bacteria [84] and they also have potential to lead to $\mathrm{pH}$ reduction, given the higher production of volatile fatty acids and lactic acid in rumen [85]. Thus, the development of methanogenic microbes is decreased in acid environment [86]. Therefore, the triple intercropping (palisade grass, pigeon pea, and corn) had higher crude protein level and possibly lowered the development of methanogenic microorganisms, decreasing the $\mathrm{CH}_{4}$ production.

Feed management that allows constant animal growth and diversification of forage species can mitigate the greenhouse gas (GHG) emissions in two ways: direct, reducing ruminal $\mathrm{CH}_{4}$ production during ruminal fermentation [87]; or indirect, caused by decrease in emission intensity (low GHG emission per unit of product) [88]. Several studies evaluated $\mathrm{CH}_{4}$ mitigation with different strategies: concentrate supplementation [89,90], fat supplementation [91,92], and ionophores [93-95]. However, 
all these options increase the production costs since they generally require more external inputs, or they may present other limitations such as rumen microbes adaptation.

Intercropping forage species can affect $\mathrm{CH}_{4}$ emissions in both ways [90]. In the present study, the intercropped silage produced $24.3 \%$ less $\mathrm{CH}_{4}$ per incubated dry matter unit and $29.0 \%$ less $\mathrm{CH}_{4}$ per DOM. The palisade grass and pigeon pea proportion in dry matter decreased e in vitro gas production (Figure 7). The intercropped silage had higher ADF and lignin levels comparing to exclusive corn silage, which probably was related to the lower digestibility and total gas production of the intercropped silage. However, the reduction of $\mathrm{CH}_{4}$ production was greater than that of total gas production, which indicated that the lower degradability was not the only explanation for $\mathrm{CH}_{4}$ reduction.

Addition of legume forages in fermentation substrates (as the pigeon pea) normally reduces $\mathrm{CH}_{4}$ production due to the presence of secondary metabolites, as tannins for example, which can modify ruminal fermentation parameters and may even present a toxic effect against methanogenic archaea, a group of microorganisms responsible for methanogenesis in the ruminal environment $[96,97]$. Melesse et al. [28] identified Acacia nilotica, Prosopis juliflora and Cajanus cajan as potential $\mathrm{CH}_{4}$ mitigators. These authors pointed out that intercropping these plants with grass as one option to increase protein input to ruminants and reduce $\mathrm{CH}_{4}$ emissions, which we observed in the present study.

\section{Conclusions}

Silage from corn, palisade grass, and pigeon pea intercropping had higher crude protein content compared to corn silage. The intercropped silage led to lower methane production compared to corn silage. The palisade grass and pigeon pea intercropped did not impact the corn growth and yield. Therefore, this intercropped system showed potential to produce a high-quality feed, decrease livestock methane emissions, and benefit the crop-livestock integrated system.

Supplementary Materials: The following are available online at http://www.mdpi.com/2073-4395/10/11/1784/s1, Table S1: descriptive analyses of variables measured, Figure S1: Scree plot showing the percentage do the variance explained by each dimension of the PCA analysis, Figure S2: First two principal components using the whole dataset, Figure S3: Contributions of the variables for each dimension in the Principal Component Analysis, Figure S4: Representation of quality of representation (cos2) for variables on the factor map of 10 dimensions, Figure S5: Significant regression results of pigeon pea (Cajanus cajan) population with the other variables of dry matter production and nutritional composition of the silage, Figure S6: Significant regression of palisade grass $(B$. brizantha) population with the other variables of dry matter production and nutritional composition of the silage.

Author Contributions: Conceptualization, E.M.A., P.D.M.T.L., A.L.A., and T.d.P.P.; data curation, P.D.M.T.L. and T.d.P.P.; formal analysis, T.d.P.P.; funding acquisition, A.L.A. and T.d.P.P.; investigation, B.L., L.F.G., F.L.C., and E.M.A.; methodology, B.L., L.F.G., F.L.C., A.M.K., B.E.B., P.D.M.T.L., and T.d.P.P.; project administration, T.d.P.P.; resources, A.L.A.; supervision, A.L.A. and T.d.P.P.; writing一original draft, B.L. and L.F.G.; writing一review and editing, E.M.A., P.D.M.T.L., A.L.A., and T.d.P.P. All authors have read and agreed to the published version of the manuscript.

Funding: This research was funded by National Council for Scientific and Technological Development (CNPq) -Brazil, grant number 468100/2014-8 and Goiano Federal Institute of Education, Science and Technology (IF Goiano), Edital n 21/2015.

Acknowledgments: We acknowledge the administrative support of Goiano Federal Institute of Education, Science and Technology (IF Goiano) Campus Iporá. We acknowledge the support of Animal Nutrition laboratory team of Center for Nuclear Energy in Agriculture (CENA) of The University of São Paulo (USP).

Conflicts of Interest: The authors declare no conflict of interest. The funders had no role in the design of the study; in the collection, analyses, or interpretation of data; in the writing of the manuscript, or in the decision to publish the results.

\section{References}

1. Kremen, C.; Iles, A.; Bacon, C. Diversified Farming Systems: An Agroecological, Systems-based Alternative to Modern Industrial Agriculture. Ecol. Soc. 2012, 17, 17. [CrossRef]

2. Anghinoni, I.; Carvalho, P.D.F.; Costa, S.D.A. Abordagem sistêmica do solo em sistemas integrados de produção agrícola e pecuária no subtrópico brasileiro. Tópicos Ci Solo 2013, 8, 325-380. 
3. De Moraes, A.; Carvalho, P.C.D.F.; Lustosa, S.B.C.; Lang, C.R.; Deiss, L. Research on Integrated Crop-Livestock Systems in Brazil. Rev. Ciênc. Agron. 2014, 45, 1024-1031. [CrossRef]

4. Hendrickson, J.R.; Hanson, J.D.; Tanaka, D.L.; Sassenrath, G. Principles of integrated agricultural systems: Introduction to processes and definition. Renew. Agric. Food Syst. 2008, 23, 265-271. [CrossRef]

5. Soussana, J.-F.; Lemaire, G. Coupling carbon and nitrogen cycles for environmentally sustainable intensification of grasslands and crop-livestock systems. Agric. Ecosyst. Environ. 2014, 190, 9-17. [CrossRef]

6. Martin, G.; Moraine, M.; Ryschawy, J.; Magne, M.A.; Asai, M.; Sarthou, J.P.; Duru, M.; Therond, O. Crop-livestock integration beyond the farm level: A review of prospects and issues. Agron. Sustain. Dev. 2016, 36, 53. [CrossRef]

7. Pariz, C.M.; Andreotti, M.; Tarsitano, M.A.A.; Bergamaschine, A.F.; Buzetti, S.; Chioderoli, C.A. Desempenhos técnicos e econômicos da consorciação de milho com forrageiras dos gêneros Panicum e Brachiaria em sistema de integração lavoura-pecuária. Pesq. Agropec. Trop. 2009, 39, 360-370.

8. Longhini, V.Z.; Andreotti, M.; De Souza, W.C.R.; Costa, N.R.; Filho, M.C.M.T.; Montanari, R. Nitrogen fertilization and inoculation with diazotrophic bacteria in corn intercropped with xaraés grass. Rev. Bras. Cienc. Agrar. 2017, 12, 340-347. [CrossRef]

9. Ramírez-Restrepo, C.A.; Vera-Infanzón, R.R.; Rao, I.M. Predicting methane emissions, animal-environmental metrics and carbon footprint from Brahman (Bos indicus) breeding herd systems based on long-term research on grazing of neotropical savanna and Brachiaria decumbens pastures. Agric. Syst. 2020, 184, 102892. [CrossRef]

10. Crusciol, C.A.C.; Mateus, G.P.; Nascente, A.S.; Martins, P.O.; Borghi, E.; Pariz, C.M. An Innovative Crop-Forage Intercrop System: Early Cycle Soybean Cultivars and Palisadegrass. Agron. J. 2012, 104, 1085-1095. [CrossRef]

11. Crusciol, C.A.C.; Nascente, A.S.; Mateus, G.P.; Borghi, E.; Leles, E.P.; Santos, N.D. Effect of intercropping on yields of corn with different relative maturities and palisade grass. Agron. J. 2013, 105, 599-606. [CrossRef]

12. Crusciol, C.; Nascente, A.S.; Mateus, G.; Pariz, C.; Martins, P.; Borghi, E. Intercropping soybean and palisade grass for enhanced land use efficiency and revenue in a no till system. Eur. J. Agron. 2014, 58, 53-62. [CrossRef]

13. Pariz, C.M.; Costa, C.; Crusciol, C.A.C.; Meirelles, P.R.L.; Castilhos, A.M.; Andreotti, M.; Costa, N.R.; Martello, J.M.; Souza, D.M.; Sarto, J.R.W.; et al. Production and Soil Responses to Intercropping of Forage Grasses with Corn and Soybean Silage. Agron. J. 2016, 108, 2541-2553. [CrossRef]

14. Pariz, C.M.; Costa, C.; Crusciol, C.A.C.; Castilhos, A.M.; Meirelles, P.; Roça, R.D.O.; Pinheiro, R.S.B.; Kuwahara, F.A.; Martello, J.M.; Cavasano, F.A.; et al. Lamb production responses to grass grazing in a companion crop system with corn silage and oversowing of yellow oat in a tropical region. Agric. Syst. 2017, 151, 1-11. [CrossRef]

15. Pariz, C.M.; Costa, C.; Crusciol, C.A.C.; Meirelles, P.R.L.; Castilhos, A.M.; Andreotti, M.; Costa, N.R.; Martello, J.M.; Souza, D.M.; Protes, V.M.; et al. Production, nutrient cycling and soil compaction to grazing of grass companion cropping with corn and soybean. Nutr. Cycl. Agroecosyst. 2017, 108, 35-54. [CrossRef]

16. Pascoaloto, I.M.; Andreotti, M.; Da Cruz, S.S.; Sabbag, O.J.; Borghi, E.; De Lima, G.C.; Modesto, V.C. Análise econômica de consórcios de sorgo com forrageiras ou guandu-anão sucedidos por soja ou milho. Pesqui. Agropecu. Bras. 2017, 52, 833-840. [CrossRef]

17. Costa, N.R.; Andreotti, M.; Buzetti, S.; Lopes, K.S.M.; Dos Santos, F.G.; Pariz, C.M. Acúmulo de macronutrientes e decomposição da palhada de braquiárias em razão da adubação nitrogenada durante e após o consórcio com a cultura do milho. Rev. Bras. Cienc. 2014, 38, 1223-1233. [CrossRef]

18. Calonego, J.C.; Raphael, J.P.; Rigon, J.P.; Neto, L.D.O.; Rosolem, C.A. Soil compaction management and soybean yields with cover crops under no-till and occasional chiseling. Eur. J. Agron. 2017, 85, 31-37. [CrossRef]

19. Snapp, S.S.; Swinton, S.M.; Labarta, R.; Mutch, D.; Black, J.R.; Leep, R.; Nyiraneza, J.; O’Neil, K. Evaluating cover crops for benefits, costs and performance within cropping system niches. Agron. J. 2005, 97, 322-332.

20. Castro, G.S.; Crusciol, C.; Calonego, J.C.; Rosolem, C.A. Management Impacts on Soil Organic Matter of Tropical Soils. Vadose Zone J. 2015, 14, 1-8. [CrossRef]

21. Costa, N.R.; Andreotti, M.; Lopes, K.S.M.; Yokobatake, K.L.; Ferreira, J.P.; Pariz, C.M.; Bonini, C.D.S.B.; Longhini, V.Z. Atributos do Solo e Acúmulo de Carbono na Integração Lavoura-Pecuária em Sistema Plantio Direto. Rev. Bras. Cienc. 2015, 39, 852-863. [CrossRef]

22. Bonetti, J.D.A.; Paulino, H.B.; De Souza, E.D.; Carneiro, M.A.C.; Da Silva, G.N. Influência do sistema integrado de produção agropecuária no solo e na produtividade de soja e braquiária. Pesqui. Agropecuária Trop. 2015, 45, 104-112. [CrossRef] 
23. De Oliveira, P.; Kluthcouski, J.; Favarin, J.L.; Santos, D.D.C. Consórcio de milho com braquiária e guandu-anão em sistema de dessecação parcial. Pesqui. Agropecuária Bras. 2011, 46, 1184-1192. [CrossRef]

24. Heinrichs, R.; Vitti, G.C.; Moreira, A.; De Figueiredo, P.A.M.; Fancelli, A.L.; Corazza, E.J. Características químicas de solo e rendimento de fitomassa de adubos verdes e de grãos de milho, decorrente do cultivo consorciado. Rev. Bras. Cienc. 2005, 29, 71-79. [CrossRef]

25. Nunes, U.R.; Andrade Júnior, V.C.; Silva, E.B.; Santos, N.F.; Costa, H.A.O.; Ferreira, C.A. Covering crops straw production and common bean productivity in no-tillage system. Pesqui. Agropecu. Bras. 2006, 41, 943-948. [CrossRef]

26. Garcia, C.M.D.P.; Costa, C.; Meirelles, P.R.D.L.; Andreotti, M.; Pariz, C.M.; Freitas, L.A.; Filho, M.C.M.T. Wet and dry corn yield under intercrop culivation with marandu grass and/or dwarf pigeon pea and nutritional value of the marandu grass in succession. Aust. J. Crop. Sci. 2016, 10, 1564-1571. [CrossRef]

27. Ferreira, L.G.; Cláudio, F.L.; Santos, L.C.; Alves, E.M.; Paim, T.P. Produção de silagem em sistemas consorciados de milho (Zea mays), guandu (Cajanus cajan) e braquiária (Urochloa brizantha). In Proceedings of the IV Congresso Estadual de Iniciação Científica do IF Goiano, Goiania, Brasil, 21-24 September 2015.

28. Melesse, A.; Steingass, H.; Schollenberger, M.; Holstein, J.; Rodehutscord, M. Nutrient compositions and in vitro methane production profiles of leaves and whole pods of twelve tropical multipurpose tree species cultivated in Ethiopia. Agrofor. Syst. 2017, 93, 135-147. [CrossRef]

29. Dias Cardoso, M.R.; Noronha Marcuzzo, F.F.; Barros, J.R. Climatic classification of Koppen-Geiger for the state of Goias and the Federal District. Acta Geogr. 2014, 8, 40-55.

30. Spaargaren, O.C.; Deckers, J. The World Reference Base for Soil Resources. In Soils of Tropical Forest Ecosystems; Springer: Berlin/Heidelberg, Germany, 1998; pp. 21-28.

31. Staff, S. Soil Taxonomy: A Basic System of Soil Classification for Making and Interpreting Soil Surveys, 2nd ed.; US Department of Agriculture Handbook; US Government Printing Office: Washington, DC, USA, 1999; p. 489.

32. Krüger, A.M.; Lima, P.D.M.T.; Filho, A.L.A.; Moro, J.D.G.; De Carvalho, I.Q.; Abdalla, A.L.; Jobim, C.C. Dry matter concentration and corn silage density: Effects on forage quality. Trop. Grassl.-Forrajes Trop. 2020, 8, 20-27. [CrossRef]

33. AOAC. Official Methods of Analysis of AOAC International, 18th ed.; Horwitz, W., Latimer, G.W., Jr., Eds.; Association of Official Analytical Chemists: Gaithersburg, MD, USA, 2011.

34. Van Soest, P.; Robertson, J.; Lewis, B. Methods for Dietary Fiber, Neutral Detergent Fiber, and Nonstarch Polysaccharides in Relation to Animal Nutrition. J. Dairy Sci. 1991, 74, 3583-3597. [CrossRef]

35. Mertens, D.R. Gravimetric determination of amylase-treated neutral detergent fiber in feeds with refluxing in beakers or crucibles: Collaborative study. J. AOAC Int. 2002, 85, 1217-1240. [PubMed]

36. Bueno, I.C.S.; Filho, S.L.C.; Gobbo, S.P.; Louvandini, H.; Vitti, D.M.; Abdalla, A.L. Influence of inoculum source in a gas production method. Anim. Feed. Sci. Technol. 2005, 123, 95-105. [CrossRef]

37. Theodorou, M.K.; Williams, B.A.; Dhanoa, M.S.; McAllan, A.B.; France, J. A simple gas production method using a pressure transducer to determine the fermentation kinetics of ruminant feeds. Anim. Feed. Sci. Technol. 1994, 48, 185-197. [CrossRef]

38. Mauricio, R.M.; Mould, F.L.; Dhanoa, M.S.; Owen, E.; Channa, K.S.; Theodorou, M.K. A semi-automated in vitro gas production technique for ruminant feedstuff evaluation. Anim. Feed. Sci. Technol. 1999, 79, 321-330. [CrossRef]

39. Longo, C.; Bueno, I.C.S.; Nozella, E.; Goddoy, P.; Filho, S.C.; Abdalla, A.L. The influence of head-space and inoculum dilution on in vitro ruminal methane measurements. Int. Congr. Ser. 2006, 1293, 62-65. [CrossRef]

40. Lima, P.D.M.T.; Moreira, G.D.; Sakita, G.; Natel, A.S.; De Mattos, W.T.; Gimenes, F.M.A.; Gerdes, L.; McManus, C.; Abdalla, A.L.; Louvandini, H. Nutritional evaluation of the legume Macrotyloma axillare using in vitro and in vivo bioassays in sheep. J. Anim. Physiol. Anim. Nutr. 2017, 102, e669-e676. [CrossRef]

41. Blümmel, M.; Makkar, H.P.S.; Becker, K. In vitro gas production: A technique revisited. J. Anim. Physiol. Anim. Nutr. 1997, 77, 24-34. [CrossRef]

42. Bates, D.; Mächler, M.; Bolker, B.; Walker, S. Fitting Linear Mixed-Effects Models Usinglme4. J. Stat. Softw. 2015, 67, 1-48. [CrossRef]

43. R Core Team. R: A Language and Environment for Statistical Computing. 2018. Available online: https://www.r-project.org/ (accessed on 13 February 2012).

44. Fox, J.; Weisberg, S. An $\{R\}$ Companion to Applied Regression, 3rd ed.; Sage: Thousand Oaks, CA, USA, 2019; Available online: https://socialsciences.mcmaster.ca/jfox/Books/Companion/ (accessed on 1 August 2020). 
45. Lenth, R.; Singmann, H.; Love, J.; Buerkner, P.; Herve, M. Emmeans: Estimated Marginal Means, Aka Least-Squares Means. R Package Version 1.4.8. 2020. Available online: https:/CRAN.R-project. org/package=emmeans (accessed on 1 August 2020).

46. Lê, S.; Josse, J.; Husson, F. FactoMineR: AnRPackage for Multivariate Analysis. J. Stat. Softw. 2008, 25, 1-18. [CrossRef]

47. Kassambara, A.; Mundt, F. factoextra: Extract and Visualize the Results of Multivariate Data Analyses. R Package Version 1.0.7. 2020. Available online: https://CRAN.R-project.org/package=factoextra (accessed on 10 August 2020).

48. Harrell, F.E.; Dupont, C. “Hmisc: Harrell Miscellaneous”. R Package Version 4.0-0. 2020. Available online: https://CRAN.R-project.org/package=Hmisc (accessed on 10 August 2020).

49. Rosseel, Y. Lavaan: An R package for structural equation modeling and more. J. Stat. Softw. 2012, 48, 1-36. [CrossRef]

50. Epskamp, S.; Epskamp, M.S.; MplusAutomation, S. Package 'semPlot'. R Package Version 1.1.2. 2019. Available online: https://cran.r-project.org/package=semPlot (accessed on 10 August 2020).

51. Kassambara, A. ggpubr: 'ggplot2' Based Publication Ready Plots. R Package Version 0.4.0. 2020. Available online: https://CRAN.R-project.org/package=ggpubr (accessed on 29 July 2020).

52. Wickham, H. ggplot2: Elegant Graphics for Data Analysis; Springer: New York, NY, USA, 2016.

53. Schreiber, J.B.; Nora, A.; Stage, F.K.; Barlow, E.A.; King, J. Reporting Structural Equation Modeling and Confirmatory Factor Analysis Results: A Review. J. Educ. Res. 2006, 99, 323-338. [CrossRef]

54. Geng, Q.; Aizizi, A.; Lai, N.; Li, Q.; Chen, S. Impact of Climatic Factors and Nitrogen Levels Drivers on Crop Yield in the Arid Region of China. Int. J. Plant Prod. 2020, 1-11. [CrossRef]

55. Strieder, M.L.; Da Silva, P.R.F.; Rambo, L.; Bergamaschi, H.; Dalmago, G.A.; Endrigo, P.C.; Jandrey, D.B. Características de dossel e rendimento de milho em diferentes espaçamentos e sistemas de manejo. Pesqui. Agropecuária Bras. 2008, 43, 309-317. [CrossRef]

56. Bayu, W.; Rethman, N.F.; Hammes, P.S. Growth and yield compensation in sorghum (Sorghum bicolorL. Moench) as a function of planting density and nitrogen fertilizer in semi-arid areas of northeastern Ethiopia. S. Afr. J. Plant Soil 2005, 22, 76-83. [CrossRef]

57. Coser, T.R.; Ramos, M.L.G.; De Figueiredo, C.C.; Urquiaga, S.; De Carvalho, A.M.; Barros, F.V.; Mendonça, M.T. Nitrogen uptake efficiency of maize in monoculture and intercropped with Brachiaria humidicola and Panicum maximum in a dystrophic Red-Yellow Latosol of the Brazilian Cerrado. Crop. Pasture Sci. 2016, 67, 47-54. [CrossRef]

58. De Oliveira, S.M.; De Almeida, R.E.M.; Junior, C.P.; Reis, A.F.D.B.; Souza, L.F.N.; Favarin, J.L. Contribution of corn intercropped with Brachiaria species to nutrient cycling1. Pesqui. Agropecuária Trop. 2019, 49, 1-9. [CrossRef]

59. Sanches, I.R.; Lazarini, E.; Pechoto, E.A.P.; Dos Santos, F.L.; Bossolani, J.W.; Parra, L.F.; Meneghette, H.H.A. Maize second-crop intercropped with forages and soil correction depths: Grain yield and forages root distribution. Res. Soc. Dev. 2020, 9, e798974778. [CrossRef]

60. Makino, P.A.; Ceccon, G.; Ribeiro, L.M.; Ceccon, F. Agronomic performance and photosynthetically active radiation intercepted by maize intercropped with brachiaria. J. Neotrop. Agric. 2019, 6, 42-48. [CrossRef]

61. Souza, W.F.; Costa, K.A.P.; Guarnieri, A.; Severiano, E.C.; Silva, J.T.; Teixeira, D.A.A.; Oliveira, S.S.; Dias, M.B.C. Production and quality of the silage of corn intercropped with Paiaguas palisade grass in different forage systems and maturity stages. R. Bras. Zootec. 2019, 48, 1-16. [CrossRef]

62. Neres, M.A.; Castagnara, D.D.; Silva, F.B.; De Oliveira, P.S.R.; Mesquita, E.E.; Bernardi, T.C.; Guarianti, A.J.; Vogt, A.S.L. Características produtivas, estruturais e bromatológicas dos capins Tifton 85 e Piatã e do feijão-guandu cv. Super N, em cultivo singular ou em associação. Cienc. Rural 2012, 42, 862-869. [CrossRef]

63. De Moraes, A.; Carvalho, P.C.D.F.; Crusciol, C.A.C.; Lang, C.R.; Pariz, C.M.; Deiss, L.; Sulc, R.M. Integrated Crop-Livestock Systems as a Solution Facing the Destruction of Pampa and Cerrado Biomes in South America by Intensive Monoculture Systems. In Agroecosystem Diversity; Elsevier BV: Amsterdam, The Netherlands, 2019; pp. 257-273.

64. Onu, P.; Okongwu, S. Performance Characteristics and Nutrient Utilization of Starter Broilers Fed Raw and Processed Pigeon Pea (Cajanus cajan) Seed Meal. Int. J. Poult. Sci. 2006, 5, 693-697. [CrossRef]

65. Amaefule, K.; Ukpanah, U.; Ibok, A. Performance of Starter Broilers Fed Raw Pigeon Pea [Cajanus cajan (L.) Millsp.] Seed Meal Diets Supplemented with Lysine and or Methionine. Int. J. Poult. Sci. 2011, 10, 205-211. [CrossRef] 
66. Stella, L.A.; Peripolli, V.; Prates, Ê.R.; Barcellos, J.O.J. Composição química das silagens de milho e sorgo com inclusão de planta inteira de soja. Bol. Indústria Anim. 2016, 73, 73-79. [CrossRef]

67. Ribeiro, M.G.; Costa, K.A.D.P.; De Souza, W.F.; Cruvinel, W.S.; Da Silva, J.T.; Júnior, D.R.D.S. Silage quality of sorghum and Urochloa brizantha cultivars monocropped or intercropped in different planting systems. Acta Sci. Anim. Sci. 2017, 39, 243-250. [CrossRef]

68. Pereira, D.; Lana, R.; Carmo, D.L.D.; Da Costa, Y.K.S. Chemical composition and fermentative losses of mixed sugarcane and pigeon pea silage. Acta Sci. Anim. Sci. 2019, 41, 43709. [CrossRef]

69. Rosa, J.R.P.; Da Silva, J.H.S.; Restle, J.; Pascoal, L.L.; Brondani, I.L.; Filho, D.C.A.; De Freitas, A.K. Avaliação do comportamento agronômico da planta e valor nutritivo da silagem de diferentes híbridos de milho (Zea mays, L.). Rev. Bras. Zootec. 2004, 33, 302-312. [CrossRef]

70. Borghi, E.; Mobricci, C.; Pulz, A.L.; Ono, E.O.; Crusciol, C.A.C. Crescimento de Brachiaria brizantha em cultivo consorciado com milho em sistema de plantio direto. Acta Sci. Agron. 2007, 29, 91-98. [CrossRef]

71. Costa, N.D.L.; Monteiro, A.L.; Silva, A.L.; De Moraes, A.; Giostri, A.F.; Stivari, T.S.; Gilaverte, S.; Baldissera, T.C.; Pin, E.A. Considerações sobre a degradação da fibra em forragens tropicais associada com suplementos energéticos ou nitrogenados. Arch. Zootec. 2015, 64, 31-41. [CrossRef]

72. Shafi, A.; Dogra, V.; Gill, T.; Ahuja, P.S.; Sreenivasulu, Y. Simultaneous Over-Expression of PaSOD and RaAPX in Transgenic Arabidopsis thaliana Confers Cold Stress Tolerance through Increase in Vascular Lignifications. PLoS ONE 2014, 9, e110302. [CrossRef]

73. Arf, O.; Meirelles, F.C.; Portugal, J.R.; Buzetti, S.; De Sá, M.E.; Rodrigues, R.A.F. Benefícios do milho consorciado com gramínea e leguminosas e seus efeitos na produtividade em sistema plantio direto. Rev. Bras. Milho Sorgo 2018, 17, 431-444. [CrossRef]

74. Patel, S.; Dhillon, N.K. Evaluation of sunnhemp (Crotalaria juncea) as green manure/amendment and its biomass content on root knot nematode (Meloidogyne incognita) in successive crop brinjal. J. Entomol. Zool Stud. 2017, 5, 716-720.

75. Salton, J.C.; Mercante, F.M.; Tomazi, M.; Zanatta, J.A.; Concenço, G.; Silva, W.M.; Retore, M. Integrated crop-livestock system in tropical Brazil: Toward a sustainable production system. Agric. Ecosyst. Environ. 2014, 190, 70-79. [CrossRef]

76. Ryschawy, J.; Choisis, N.; Choisis, J.P.; Joannon, A.; Gibon, A. Mixed crop-livestock systems: An economic and environmental-friendly way of farming? Animal 2012, 6, 1722-1730. [CrossRef] [PubMed]

77. Varshney, R.K.; Penmetsa, R.V.; Dutta, S.; Kulwal, P.L.; Saxena, R.K.; Datta, S.; Dubey, A. Pigeon pea genomics initiative (PGI): An international effort to improve crop productivity of pigeon pea (Cajanus cajan L.). Mol. Breed 2010, 26, 393-408. [CrossRef] [PubMed]

78. Ferreira, E.P.D.B.; Stone, L.F.; Partelli, F.L.; Didonet, A.D. Produtividade do feijoeiro comum influenciada por plantas de cobertura e sistemas de manejo do solo. Rev. Bras. Eng. Agrícola Ambient. 2011, 15, 695-701. [CrossRef]

79. Sekhon, F.S.; Singh, T.; Singh, S. Growth, phenology and yield of pigeon pea (Cajanus cajan) as affected by intercropping systems and application of nutrients level to intercrops. Indian J. Agric. Sci. 2018, 88, 509-514.

80. Beever, D.E.; Dhanoa, M.S.; Losada, H.R.; Evans, R.T.; Cammell, S.B.; France, J. The effect of forage species and stage of harvest on the processes of digestion occurring in the rumen of cattle. Br. J. Nutr. 1986, 56, 439-454. [CrossRef]

81. Manella, M.D.Q.; Lourenço, A.J.; Leme, P. Recria de bovinos Nelore em pastos de Brachiaria brizantha com suplementação protéica ou com acesso a banco de proteína de Leucaena lecocephala: Características de fermentação ruminal. Rev. Bras. Zootec. 2003, 32, 1002-1012. [CrossRef]

82. Oliveira, V.D.S.; Neto, J.A.S.; Valença, R.D.L.; Da Silva, B.C.D.; Dos Santos, A.C.P. Carboidratos fibrosos e não fibrosos na dieta de ruminantes e seus efeitos sobre a microbiota ruminal. Veterinária Notícias 2016, 22, 22. [CrossRef]

83. Berchielli, T.T.; Messana, J.D.; Canesin, R.C. Produção de metano entérico em pastagens tropicais. Rev. Bras. Saúde Produção Anim. 2012, 13, 954-968. [CrossRef]

84. Church, D.C. The Ruminant Animal: Digestive Physiology and Nutrition; Waveland Press: Englewood Cliffs, NJ, USA, 1988; p. 563.

85. Oliveira, V.S.; Santana Neto, J.A.; Valença, R.L. Características químicas e fisiológicas da fermentação ruminal de bovinos em pastejo-Revisão de literatura. Rev. Cient. Eletronica. Med. Vet. 2013, 20.

86. Moreira, P.C.; de Camargo Wascheck, R.; Dutra, A.R.; Grandsire, C.; de Almeida, O.C.; Moreira, S.D.O.L. Pectina: Um carboidrato complexo e suas aplicações. Rev. Cienci. Ambient. Saude 2008, 35, 343-355. 
87. Savian, J.V.; Schons, R.M.T.; Marchi, D.E.; De Freitas, T.S.; Neto, G.F.D.S.; Mezzalira, J.C.; Berndt, A.; Bayer, C.; Carvalho, P.C.D.F. Rotatinuous stocking: A grazing management innovation that has high potential to mitigate methane emissions by sheep. J. Clean. Prod. 2018, 186, 602-608. [CrossRef]

88. Cottle, D.J.; Nolan, J.V.; Wiedemann, S.G. Ruminant enteric methane mitigation: A review. Anim. Prod. Sci. 2011, 51, 491-514. [CrossRef]

89. Lovett, D.; Lovell, S.; Stack, L.; Callan, J.; Finlay, M.; Conolly, J.; O’Mara, F. Effect of forage/concentrate ratio and dietary coconut oil level on methane output and performance of finishing beef heifers. Livest. Prod. Sci. 2003, 84, 135-146. [CrossRef]

90. Martin, C.; Morgavi, D.P.; Doreau, M. Methane mitigation in ruminants: From microbe to the farm scale. Animal 2009, 4, 351-365. [CrossRef]

91. Johnson, K.A.; Johnson, D.E. Methane emissions from cattle. J. Anim. Sci. 1995, 73, 2483-2492. [CrossRef]

92. Boadi, D.; Benchaar, C.; Chiquette, J.; Massé, D. Mitigation strategies to reduce enteric methane emissions from dairy cows: Update review. Can. J. Anim. Sci. 2004, 84, 319-335. [CrossRef]

93. Guan, H.; Wittenberg, K.; Ominski, K.H.; Krause, D.O. Efficacy of ionophores in cattle diets for mitigation of enteric methane1. J. Anim. Sci. 2006, 84, 1896-1906. [CrossRef]

94. Odongo, N.; Bagg, R.; Vessie, G.; Dick, P.; Or-Rashid, M.; Hook, S.; Gray, J.; Kebreab, E.; France, J.; McBride, B. Long-Term Effects of Feeding Monensin on Methane Production in Lactating Dairy Cows. J. Dairy Sci. 2007, 90, 1781-1788. [CrossRef]

95. Patra, A.K. Enteric methane mitigation technologies for ruminant livestock: A synthesis of current research and future directions. Environ. Monit. Assess. 2011, 184, 1929-1952. [CrossRef] [PubMed]

96. Patra, A.K.; Saxena, J. Exploitation of dietary tannins to improve rumen metabolism and ruminant nutrition. J. Sci. Food Agric. 2010, 91, 24-37. [CrossRef] [PubMed]

97. Liu, H.; Vaddella, V.; Zhou, D. Effects of chestnut tannins and coconut oil on growth performance, methane emission, ruminal fermentation, and microbial populations in sheep. J. Dairy Sci. 2011, 94, 6069-6077. [CrossRef] [PubMed]

Publisher's Note: MDPI stays neutral with regard to jurisdictional claims in published maps and institutional affiliations.

(C) 2020 by the authors. Licensee MDPI, Basel, Switzerland. This article is an open access article distributed under the terms and conditions of the Creative Commons Attribution (CC BY) license (http://creativecommons.org/licenses/by/4.0/). 